\title{
Human Capital Development in Science and Technology Education: Challenges and New Responsibilities of the Teacher
}

\author{
Kennedy O. Odu \\ Delta State University, Nigeria
}

\begin{abstract}
The importance of science and technology education cannot be over-emphasized. Human capital development in science and technology education is the gateway to a scientific, technological, and progressive society. It is also the very bedrock upon which modern and advanced nations are based. However, science was featured in a few secondary and teacher training schools in Nigeria between 1859 and 1929. The major subjects taught in the schools were astronomy, chemistry, physiology, geology, and botany. These were later systematized and then changed first to Nature Study and later General Science. Training of technology education teachers in Nigeria started in 1962 with the establishment of the Department of Vocational Teacher Education at the University of Nigeria-Nsukka under the supervision of Michigan State University (USA) at its formative years. Human capital development in science and technology education is faced with a lot of challenges such as retraining of science and technology teachers, dearth of qualified technology trainers, and inadequate funding among others. This paper addressed how these challenges could be forestalled for successful implementation of human capital development and also the new responsibilities of the teachers for science and technology education in Nigeria.
\end{abstract}

Keywords: Human capital development; Technology education; Science education; Training of science and technology teachers

\section{The Concept of Science Education}

Science may be looked at as a human enterprise. It is primarily and usually connected with finding out about the human environment (Buseri, 1995). Inomiesa (1993) sees science as "the what", "the how", and "the why" of everything happening in our environment. Science (Inomiesa, 1997) is made up of two important parts. These are products (knowledge) and processes (methods). The products usually deal with the facts, concepts, laws, principles and/or generations and they come to us in the form of classificational, correlational and theoretical concepts.

Science, with the above understanding, was featured in very few secondary and teacher training schools in Nigeria between 1859 and 1929 (Inomiesa, 2010). The major subjects taught were astronomy, chemistry, physiology, geology, and botany. These were later systematized and then changed first to Nature Study and later General Science. 
The first schools in Nigeria were established by private bodies - the missionaries. So initially government did not take part in the establishment and running of schools. What the government did was the engagement of teachers that were later handed over to the missionaries. It was much later that government established a number of schools of which few of them taught science subjects. Following this, tribal groups, community affiliations, and a number of town union associations established their own schools run on the terms established. In the second half of the $19^{\text {th }}$ century, three patterns of schools emerged. These were: the grammar schools; the teacher training and the pastor training institutions; the vocational and agricultural schools. The teaching of science in secondary schools was very elementary. There were fewer schools and fewer students than now doing science. There were very few science teachers especially those qualified to teach science, others were Advanced Level and Certificated Grade I and II teachers from the Teacher Training Colleges. Sizeable and well equipped laboratories existed to make science more real and practical.

Presently (Inomiesa, 2010) observed that science is taught as biology, chemistry, and physics. The syllabus has been increased tremendously. Some of the teachers teaching in these schools can be said to be qualified. They hold the following degrees: B.Sc, HND, B.Sc (Ed), B.Sc. Plus NCE, or B.Sc plus Postgraduate Diploma in Education.

\section{The Concept of Technology Education}

Technology education which is synonymous with technical education, industrial technical education, and industrial arts is defined by the National Policy on Education (Federal Republic of Nigeria-FRN, 2004) as an aspect of the educational process involving, in addition to general education, the study of technologies and related sciences and the acquisition of practical skills, attitudes, understanding, and knowledge relating to occupations in various sectors of economic and social life. Technology education is further understood to be:

- an integral part of general education;

- a means of preparing for occupational fields and for effective participation in the world of work;

- an aspect of lifelong learning and a preparation for responsible citizenship;

- an instrument for promoting environmentally sound sustainable development;

- A method of alleviating poverty.

The goals of technology education according to the National Policy on Education in Nigeria can be listed as follows:

- provide trained manpower in the applied sciences, technology, and business particularly at craft, advanced craft, and technical levels;

- Provide the technical knowledge and vocational skills necessary for agricultural, commercial, and economic development; 
- Give training and impart the necessary skills to individual who shall be self-reliant economically.

Science and technology are related in the sense that science is the input while technology is the output. Technology education is the teaching and learning of technology subjects in order to acquire practical skills.

\section{Human Capital Development in Technology Education}

Human capital development in technology education is vital to national development. Hand tools, machines, instructional materials, and infrastructural facilities may be available in abundance but without the trained manpower that will manage these facilities, learning cannot take place in the school.

According to the National Policy on Education (FRN, 2004), no education system may rise above the quality of its teachers. Therefore, human capital development in technology education is paramount to sustainable development. Human capital development according to Ogbaunya and Usoro (2009) is a process of improvement that embraces all those activities that are geared towards the growth and improvement of skills, knowledge and attitude of personnel. A teacher who is not currently in tune with modern trend is dangerous to the system. Staff development in terms of continuing education appears rather very poor, haphazard, politicized, and lack needed continuity. Dryaklor (1994) asserted that teachers need to be retrained two to six times in lifetime to keep abreast with changes in their profession. The initial attempt by the Federal Government of Nigeria to retrain technical teachers was a failure because such teacher under Technical Teachers Training Programme (TTTP) never came back and even those that came back settled on greener pasture.

Any government that encourages its citizen to be creative and innovative must be conscious of the quality and quantity of teachers in the system. Maduewesi (2005) stated that the issue of human capital development is perhaps the upper most concern of educational planners and administrators while Onwuka and Gladys (2010) define human capital development as the process of attaining professionalism through acquisition of necessary knowledge, skills, and attitudes for competence and effective performance in the job.

Human capital development in Nigeria has metamorphosed tremendously. Currently, categories of teachers practicing it include B.Ed/BA/B.Sc, M.Ed., Ph.D, NCE and TC II (almost in extinction) Nigerian Certificate of education (NCE) is the minimum teaching qualification in Nigeria. There are bodies in-charge of teachers' preparation in Nigeria. The National Policy on Education (FRN, 2004) charged the following bodies with the responsibility of human capital development at various levels: Colleges of Education, Faculties of Education, School of Post-Graduate Studies, Institutes of Education, National Teacher's Institute, and Schools of Education in Polytechnics. The Federal Government charged the Teachers Registration Council of Nigeria with the responsibility of registration of professional teachers and with institute standard. These are efforts to make human capital development efficient. Despite the process made so far in human capital development there are still problems. Most of the bodies charged with the preparation of programs still 
produce teachers with inadequate skills to fit into the contemporary society. Obanya (2002) noted that teacher preparation programs are still based predominantly on traditional practices. Most teacher preparation programs neglect creativity, innovativeness, and risk taking which are basic ingredients of entrepreneurship education.

\section{Brief History of Human Capital Development in Technology Education in Nigeria}

Teacher training in technology education in Nigeria started in 1962 with the establishment of the Department of Vocational Teacher Education at the University of Nigeria, Nsukka. This department relied heavily on the Michigan State University (USA) for technical and material support during its formative years. Later, the Federal Colleges of Education (Technical) at Akoka and Gombe were established while institutions such as the Yaba College of Technology, Institute of Management and Technology in Enugu; Kaduna Polytechnic, and Ibadan Polytechnic also ventured into the area of technical teacher training as parts of their programs. In 1979, when the new educational system required all secondary schools in the country to offer technical subjects, these institutions proved to be grossly inadequate to meet the nation's needs for technology education teachers.

The paucity of technology education teachers and their critical nature to the successful implementation of the 6-3-3-4 system of education became apparent after the Federal Government had procured technical equipment and distributed them to secondary schools. For many years, some of these equipment remained locked up in their containers some were stolen while some others were misused and destroyed. Consequently, in order to enhance successful implementation of the 6-3-3-4 education system and prevent further wastage of the equipment already procured, the Federal Government entered into bilateral agreements with the governments of the United States of America (US.) for the training of technology education teachers. Tailor (1986) reported that the projection was for the nation to produce 500 technology education teachers yearly over a period of ten years.

Starting from 1980, young Nigerians were sent abroad to be trained as technology education teachers. Many of those sent were holders of the NCE, B.Ed/B.Sc,, HND, FTC and their scholarship was for a minimum of two years leading to at least bachelors degree in technical/technology area; some of those sent also went for master's degrees in technical/technology fields. The technical teacher training programmed in America continued for about ten years (1980-1990) before it was phased out.

In 1992, the Technical Teacher Training Programme (TTP) which was run in America was domiciled in Nigeria owing to the deregulation policy that led to the Structural Adjustment Programme (SAP). The Federal Government could not foot the bill for the training of the technology education teachers in America. According to Olaitan (1994), the value of the naira embarked on a sharp decline and by 1990, ten naira hardly exchanged for one dollar. The domestication of the Technical Teachers Programme in Nigeria was approved by the then Honorable Minister of Education and Youth Development, Professor Aliu Babatunde Fafunwa.

The program took off in January 1992 with an initial intake of 500 students placed in four institutions including University of Nigeria at Nsukka and Ahmadu Bello University in Zaria. The 
second set of intakes made up of a total of 545 students were placed in programs in January 1993 and this is a signal that the nation might now achieve the goal of self-sufficiency in human capital development in technology education but this was not true. The following important challenges (Olaitan 1994) confronted the implementation of the Technical Teacher Training Programme in Nigeria.

\section{Insufficient Material Resources for Training}

With the take off of the domesticated TTTP, participating institutions have had to take on more students than available machines, equipment, and other materials can adequately cater for. With good management skills, some of these institutions were able to maximize the use of available resources. However, the fact remains that these institutions would do with more material resources, especially those that would replace obsolete equipment.

\section{Dearth of Qualified Technical Educators}

There is a severe shortage of suitably qualified technical educators in both the participating institutions and other institutions that have been marked for involvement in the program in the future. Moreover, some of the existing technical educators or teachers were either trained on obsolete equipment or have worked with such equipment for so long that their skills need to be updated. The training and re-training of technical educators is therefore of paramount importance in the success of the domesticated TTTP.

\section{Release of Participating Students for TTTP}

There were complaints from some students that their participation in the TTTP does not receive the full support and co-operation of some of their heads of institutions. As a result, some of these students were not released fully for the program even when they have been accepted and duly placed. This situation could be very frustrating to both the students concerned and cocoordinators of the TTTP. Heads of Institutions should help in releasing the participants since they will return to them after their training to comply with the terms of their agreements.

\section{The Need to Extent the Program to Applicants Who Are Not Already Teaching}

Most participants of the TTTP are those who are already teaching. At best, these students would become more competent technical teachers. However, for successful implementation of the national policy on education, it is equally important to increase drastically the number of technical teachers in the system. Thus, the extension of the TTTP to young school leavers and to the unemployed should be explored for the purpose of increasing the number of technical teachers now on the field. 


\section{Use of the Quota System for Selection of Students in TTTP Programme}

The need to increase the quality and quantity of technical teachers cuts across all states of the federation. As a result, the quota system must be seen to be effective in the TTTP program. All states of the federation must be represented in the program.

\section{Challenges of Human Capital Development}

Human capital development or the recruitment and training of technology teachers that would mean the various technology education programs in different levels of institutions may encounter some difficulties if urgent remedies are not taken. The most important challenges in this context are mentioned below.

\section{Re-training of Technology Teachers}

Some existing technology teachers were either trained on obsolete equipment or have worked with such equipment for a long time that their skills need to be updated. Therefore, training and re-training of teachers is extremely vital for successful implementation of teaching and learning strategies in schools.

Retraining means receiving in-service education. It implies subjecting, or exposing an individual to further teaching and practice after the initial training. It may also be taken as improving the teacher. Our society is dynamic. Our needs, values, aspirations, and expectations change from time to time. Knowledge, skills, and methodologies also change as a result of research since education is the fastest tool for socialization and propagation of culture. Teachers are tools used to implement the teaching and learning process, all technology education teachers should be retrained on a regular basis. Dryaklor (1994) asserted that teachers need to be re-trained two to six times in their lifetime to keep abreast with changes in his profession.

The Avenues for retraining technology education teachers according to Iwuanyanwu (1998) include:

- Attending and participating actively in seminars, conference, and workshops;

- Belonging to some professional associations where the teachers can meet with experienced colleagues to exchange ideas and talks about new happenings and developments (innovations) in teaching and professional teachers' education.

- Departmental or in-house seminars, conferences, and workshops where senior or more experienced colleagues help the others to improve their lots.

- Higher training through part-time programs, sandwich programs, and full-time study leave with pay.

The main purpose of retraining of technology teachers is to improve their qualities, expertise, competence, efficiency, and effectiveness. 


\section{Dearth of Qualified Technology Education Trainers}

Trainers of technology education are very few in all levels of technology education. Factors which hinder good human capital development could be traced to the acute shortage of suitably trained and qualified teachers. According to Akpan (2001), the reason for the shortage could be traced to unattractiveness of the teaching profession such that it is difficult to recruit and retain technical teachers at all levels of educational system. For instance, in the junior secondary schools in Delta State, a total of 698 vocational/technical teachers are available for teaching the pre-vocational subjects for the $2007 / 2008$ session. Out of this number, 673 (96.4\%) are qualified while 25 (3.6\%) are unqualified teachers (Akpotu \& Okonta 2010). According to the authors, the students/teachers ratio is $155: 1$. Details of the number of vocational/technical teachers currently available in junior secondary schools are shown in the table below.

Table 1. An Analysis of Differences between Available and Required Number of Vocational/ Technical Teachers

\begin{tabular}{|c|c|c|c|c|c|c|c|}
\hline \multirow[t]{2}{*}{$\begin{array}{l}\text { Pre-Vocational Subject } \\
\text { Areas }\end{array}$} & \multirow[t]{2}{*}{$\begin{array}{r}\text { Number of } \\
\text { Students } \\
\text { Per Subject }\end{array}$} & \multicolumn{2}{|c|}{$\begin{array}{r}\text { Number of } \\
\text { Available } \\
\text { Voc/Tech. } \\
\text { Teachers } \\
\end{array}$} & \multirow[t]{2}{*}{$\begin{array}{r}\text { Student/ } \\
\text { Teacher } \\
\text { Ratio Per } \\
\text { Subject }\end{array}$} & \multirow[t]{2}{*}{$\begin{array}{r}\text { Overall } \\
\text { Student/ } \\
\text { Teacher } \\
\text { Ratio }\end{array}$} & \multirow[t]{2}{*}{$\begin{array}{l}\text { Number of } \\
\text { Required } \\
\text { Teachers. }\end{array}$} & \multirow{2}{*}{$\begin{array}{r}\text { Differences } \\
\text { between } \\
\text { Available } \\
\text { and } \\
\text { Required } \\
\text { Teachers } \\
\end{array}$} \\
\hline & & $Q$ & $\mathrm{NQ}$ & & & & \\
\hline Intro. to Technology & 20,061 & 63 & 3 & 318:1 & & 502 & 439 \\
\hline Practical Agriculture & 23,558 & 208 & 16 & 113:1 & & 589 & 381 \\
\hline Business Studies & 24,454 & 189 & 4 & 129:1 & & 611 & 422 \\
\hline Home Economics & 24,724 & 184 & 1 & $134: 1$ & 155:1 & 618 & 434 \\
\hline Local Crafts & 7,039 & 11 & 1 & 640:1 & & 176 & 165 \\
\hline Computer Education & 4,362 & 18 & 0 & 242:1 & & 109 & 91 \\
\hline Total & 104,198 & 673 & 25 & & & 2,605 & 1,932 \\
\hline Grand Total & & 65 & & & & & \\
\hline
\end{tabular}

Source: Computed from fieldwork in (Akpotu \& Okonta, 2010)

Comparing the ratios obtained per subject to the National Policy on Education's standard of 40:1, it can be rightly inferred according to (Akpotu \& Okonta, 2010) that there are inadequate numbers of vocational/technical teachers in junior secondary schools in Delta State. To buttress the study of Akpotu and Okonta that there is inadequate technology education teachers to handle technical subjects, the NERDC report of the state of demand and supply in 1997 revealed that about 270,000 vocational technical teachers nationwide representing $74 \%$ of total need were not available (Aina, 2000). This signifies that only $26 \%$ of such teachers are on ground.

\section{Inadequate Funding}

Technology education is capital-intensive and cannot be adequately implemented with poor funding. Technical and applied skills could not manifest from ordinary reading of handouts and pictures of stimulated tools and equipment (Olaitan 1996). Due to poor funding, workshops are 
either empty or stored with outdated tools and equipment. This problem has greatly reduced the quality of human capital development in technology education.

\section{Poor Workshop Organization}

Teacher trainees are faced with problems of workshop organization as they find it difficult to translate theories imparted into practical experiences. They cannot effectively impart skills as the training environment is not the functional working environment. It must not just be any kind of technology education but a right type of education with workshop facilities for creativity, hard work and discipline. This will guarantee quality human capital development. What is described as workshop in most technical trade areas is only a classroom with few tools and equipment and where the workshop is available, it serves as a number of units, thereby providing limitations for practical exercises. As ascertained to Idika (1997), one of the major reasons why some technical teachers leave the teaching field could be the non-provision of adequate training facilities such as laboratories, workshops, and classrooms.

\section{Inadequate Instructional Materials}

The quality of education in Nigeria has fallen in the area of facilities for learning. Odukwe (2003) observed that from primary school to tertiary institution the facilities, infrastructure, and learning aids are no longer available. This signifies that the population of the teacher trainees admitted out-weighs the capacity of facilities available. Fajemirolum (2003) asserted that the situation appears so bad in the universities that more than ten technical teacher trainees were regularly assigned to one instructional material with equipment in a crowded workshop. This may hinder good interaction and opportunity for effective workshop experiences.

\section{Strategies for Improving Human Capital Development in Technology Education}

Technology has created innovation in industry, segment and component of the society, economy, and culture yet has not done so much in human capital development. The following measures are suggested to improve human capital development.

\section{The Use of ICT in Teaching and Learning}

In order to be relevant in the information age, the teacher training institutions should stay current as a successful teacher should keep pace with changes in their field and with times. Teacher training institutions should be equipped with Information and Communication Technology (ICT) to assist the teacher learn how ICT is being used. ICT tool has the ability to shift focus of classroom teacher-centered to student-centered learning. This allows students to actively participate in classroom transaction as they produces and share knowledge. Ogbuanya and Usoro (2009) maintained that ICT is also a catalyst for paradigm shift to new training approaches within an 
organization. Companies and industries have now begun to look beyond traditional classroom instruction to meet their training need.

\section{Entrepreneurship Training}

To improve business technique in technical teacher education, entrepreneurial skills of marketing skills, financial management, self-motivation, time-management, administrative skills, professional skills, and innovative skills should be intensified and emphasized to the total development of the individual trainees (Hisrich, Peters, \& Shepherd, 2008).

According to Nwaokolo (2003), the training for entrepreneurship must be in addition to the usual skills training in any of the technology areas since a typist, for example, without adequate typing skills is not likely to succeed even when encouraged to open a business center. It is therefore very important that the introduction of entrepreneurship education will involve the finance of all technology graduates in this manner. Perhaps it is important to stress that in a period of mass unemployment and declining economic fortunes as happened in recent years, only the best can survive. The foregoing has pointed out and dealt with curriculum implication of entrepreneurship for technology education.

\section{Application of Appropriate Methodology in Teaching Technical Subjects}

For quality human capital development in science and technology education this paper advocates constructivist philosophy in pedagogy. The emerging theory of constructivist learning may have implication for science and technology education in this century. It would help in the preparation of workers for entry into and advance in the workplace as the $21^{\text {st }}$ century requires an educational program that provides not only job skills as science and technology education did throughout the 1900 s but also higher order thinking, problem solving, and collaborative work skills (Ogbaunya \& Usoro, 2009).

\section{Curriculum Innovation}

The curriculum of teacher training institutions in the field of science and technology should move away from the traditional courses to embrace computer installation and maintenance, graphical arts, petrochemical, instrumentation, food technology, land surveying, metallurgical technology, glass and telecommunication technology and so on. The curriculum of science and technology education should also focus more on creativity education. Often industries and colleges reject products of science and technology education whose training was based on the outdated method of developing skills such as "Do as I do and repeat after me". To this end, training institutions in the area of science and technology education should shift focus to curriculum that acknowledges particular set of talents and attempt to enable the trainee discover and develop his particular sets of potentials. 


\section{Provision of Training Facilities}

Science and technology education according to Egboh (2009) cannot be effectively implemented in schools without workshop facilities, laboratories, functional tools, studios, and equipment with constant supply of electricity. The state and the federal government of Nigeria should intensify effort to supply and replace outdated tools and equipment, expand the existing workshop, laboratories and training facilities to ensure that science and technology education environment depicts the working environment.

\section{The New Responsibilities of the Teacher in Human Capital Development}

In the $21^{\text {st }}$ century, a lot of responsibilities are demanded from the teachers in human capital development. In addition to the one indicated so far, relatively new responsibilities in this area can be summarized as follows:

\section{Teachers Being Knowledgeable in ICT}

The intention of the Federal Government of Nigeria to introduce computer education in the teaching curriculum suggested that science and technology teacher trainee should be provided with enabling environment that encourages individualized learning, which is one of the modern approaches for learning of science and technology. In human capital development, the use of ICT will enable the trainers to get more effective results in teaching. Similarly, teaching and learning becomes easier.

\section{Improvement on Teaching Strategies}

Arubayi, Nworgu, Akpochafor and Odu (2008) suggested the following teaching strategies in science, technology, and vocational education that will enhance skill acquisition among teachers and learners in Nigerian secondary schools: (a) Concept formation; (b) Real Life Application; (c) Job-related skills acquired by learners; (d) Demonstration; (e) Equipment, care, and maintenance; (f) Diagrams/illustrations/Drawings.

\section{Conclusion}

Human capital development in science and technology education is essential to human and educational development. Unfortunately, a lot of challenges are facing this very important issue concerning technology education. These problems are: retraining of science and technology teachers, dearth of qualified technology education trainers, inadequate funding, poor workshop organization, and inadequate instructional materials. A number of strategies are recommended in this paper to make human capital development in science and technology education successful. The most important of these can be highlighted as the effective use of ICT in teaching and learning 
processes, entrepreneurship training, application of appropriate methodology in teaching science and technology, curriculum innovation, and provision of training facilities.

\section{References}

Aina, O. (2000). Nigeria technical and vocational education in the near future. Keynote address at National Seminar on Technical and Vocational Education in Nigeria held at National Centre for Women Development. Abuja, Nigeria.

Akpan, A. A. (2001). Technical skills acquisition among undergraduates during industrial work. Nigerian Vocational Journal, 4(1), 41-51.

Akpotu, N. E. \& Okonta, V. (2010). An assessment of human resource need for pre-vocational education in junior secondary schools in Delta State. Paper Presented at the 2010 Annual General Conference of Institute of Education, Delta State University. Abraka, Nigeria.

Arubayi, E., Nworgu, B. G., Akpochafo, W., \& Odu, K. O. (2008). Manual for monitoring curriculum contents of subject inspection in senior secondary schools. Inspectorate Division, Federal Ministry of Education. Abuja, Nigeria.

Buseri, J. C. (1995). Principle of science education and teaching. Port Harcourt: BUCIL.

Dryaklor, N. (1994). The scientific and technology revolution: It's role in today's world. Moscow: Progress Publishers.

Egboh, S.H.O. (2009). Strategies for improving the teaching of science, technical and vocational education in schools and colleges in Nigeria. Paper Presented at the one day Intensive Nationwide Training/Workshop Organized by the Centre of Science, Technical and Vocational Education Research Development, Jos and Proprietors of Private Schools in Delta State held at College of Education. Warri, Nigeria.

Fajemirolum, C. T. O. B. (2003). Curriculum innovations for sustainable technology education in Nigeria: Training and retraining of Nigerian technologist. Nigeria Association of Teachers of Technology (NATT), 1(2) 46-51.

Federal Republic of Nigeria. (2004). National policy on education $\left(4^{\text {th }}\right.$ edition). Yaba, Nigeria: NERDC.

Hisrich, R. D., Peters, M. P., \& Shepherd, D. A. (2008). Entrepreneurship. New York: McGraw-Hill.

Idika, V. (1997). Factors that influence retention of technical teachers in Abia State secondary schools (Unpublished M.Ed. Thesis). University of Nigeria, Nsukka.

Inomiesa, E. A. (1993). Developing primary school science test for continuous assessment of primary six pupils. Review of Education, 13, 115-126.

Inomiesa, E.A. (1997). Secondary schools' evaluation of secondary school chemistry teachers. Studies in Education, 1(2\&3). 46-70.

Inomiesa, E. A. (2010). Teaching of science in Nigerian secondary schools: the beginning, the present and the future. $20^{\text {th }}$ in the Series of Inaugural Lectures of Delta State University, Abraka, Nigeria. Abraka, Nigeria: University Printing Press. 
Iwuanyanwu, C. N. (1998). The need for the pre-service and in-service education experience for the pre-school teacher. The Asaba Educator: Technical and Science Journal, 1(1), 26-31.

Maduewesi, E. J. (2005). Benchmarks of global trends in education: Benin City: Dasylva Influence Enterprises.

Nwaokolo, P. O. (2003). Recent experiences in educational alternatives in Africa: The post-primary technology education case. In N. P. M Esomonu, K. O. Odu, D. O. Eluro, \& J. O. Chukwusa (Eds.), Related thoughts in vocational education. The Developing world experience (pp. 116128). Awka, Nigeria: MarPat Educational Research and Publishers.

Obanya, P. A. T. (2002). Revitalizing education in Africa. Lagos, Nigeria: Sterling Holden Publishers.

Odukwe, M. (2003, October 10). Standard of education has fallen. Punch Newspaper. 18-19.

Ogbaunya, T.C. \& Usoro, A.D. (2009). Quality teacher preparation for effective implementation of technical education in Nigeria. Nigerian Vocational Journal, 14(1), 41-51.

Olaitan, S. O. (1994). Domestication of the technical teacher training programme and its implications for sustainable economic development. Journal of Technical Teacher Education, 1(2), 10-14.

Olaitan, S. O. (1996). Vocational and technical education in Nigeria (Issues and Analysis). Onitsha: Noble Graphic Press.

Onwuka, E. M. \& Gladys, O. U. (2010). Development and validation of Entrepreneurial Skills Assessment Inventory of Youths. Unizik Orient Journal of Education, 5(2), 167-175.

Tailor, G. A. (1986). Presidential address. NATT Conference. Kaduna.

Correspondence: Kennedy O. Odu, Senior Lecturer, Department of Technical and Business Education, Delta State University, Abraka, Delta State, Nigeria 